\title{
The Fun Food Barbeque as a Product Innovation of the Food and Beverage Department, the Neo+ Awana Hotel, Yogyakarta
}

\author{
CARLOS IBAN \\ Tourism Program, Vocational College, Universitas Gadjah Mada \\ carlosiban@ugm.ac.id
}

\section{ARISMAGITA}

Tourism Program, Vocational College, Universitas Gadjah Mada

arismagita@mail.ugm.ac.id

\begin{abstract}
The growth of the hotel business in Yogyakarta is currently increasing up. Based on data from the Association of Indonesian Hotels and Restaurants, the total of new hotels to be built in Yogyakarta reaches 110 hotels. With reference to these growth figures, hospitality management is currently not only focused on providing accommodation, but also going further to selling other hotel products, such as food and beverages. This research took a case study about the product innovation of Neo+ Awana Hotel Yogyakarta, with a developing event called "Fun Food Barbeque". The method used is descriptive qualitative with primary data collection using participant observation and interviews. The results shows that the first implementation of the Barbeque Fun Food event is not optimal, because guests are not interested in western food and also the menu has many things to offer. With the changing innovation of barbecue products into fusion food with a menu that is a blend of Indonesian food with western food, the Fun Food Barbeque event becomes more interesting.
\end{abstract}

Keywords:

Hotel, Product, Food, Innovation, Neo+ Awana Yogyakarta 


\section{INTRODUCTION}

The hospitality industry is one of the largest sectors in the global tourism industry. This can be seen from the contribution of this industry in supporting the economic development of a region (UNWTO, 2012). Indonesia is one of the global emerging tourist destinations that want to increase its competitiveness by build various tourism infrastructures, especially hotels. The construction of the hotel has become widespread with increasing tourist attraction in Indonesia. The rapid development of tourist accommodation has prompted many investors to build various types of hotels in areas that are experiencing economic growth in the tourism sector.

Yogyakarta Special District is a province in Indonesia with high numbers of tourist visits. The high volume of tourist visits affects the number of local and foreign investors to build hotels, from a one-star hotels to five-star hotels. Based on data from the Association of Indonesian Yogyakarta Hotels and Restaurants in the period of 2015-2016, a total of 110 new hotels will be built which are star hotels and economy hotels (Tribun Jogja, 2015). Nowaday, the hotel industry investors are not only focusing on accommodation providers, but also optimizing the sale of other hotel products. One of them is the product from the Food and Beverage department. These products are not only sold to hotel guests who stay overnight but also to guests who do not stay overnight. From these food and beverage products, hotels generate more revenue so that each hotel will offer a variety of different flagship products to attract guests.

Seeing the trend in the global tourism industry, the hospitality industry in the city of Yogyakarta has also optimized the sales of various products from the Food and Beverage Department. The optimization efforts can be seen from the rise of advertisements and promotions that sell food and beverage products through various media, both print and internet. The high number of new hotels that established in the city of Yogyakarta makes new hotels have to compete with other hotels that already have existence. Therefore, new hotels must make creations and innovations to display the best products in order to compete with other hotels.

Neo+ Awana Hotel is one of the hotels that is strategically located close to the city center and the main tourist attractions of Yogyakarta. Neo+ Awana Hotel itself was opened in March 2015. This hotel is still developing various products, especially on food and beverage. One of the innovative products from the hotel is an event called "Fun Food Barbeque". This event is run in every weekend on Friday to Saturday. The event is not only for staying guests at the hotel but also for tourists who visiting Yogyakarta.

The product innovation underlies the authors to do the research on how the innovation of the product of the Food and Beverage department come to attract the consumers. Based on the description of the research background, the authors formulate the problem into two research questions: (1) What are the products offered in the Fun Food Barbeque Event at Neo+ Awana Hotel Yogyakarta? (2) What are the innovations made by the Food and Beverage Department in preparing for the Fun Food Barbeque event? Based on the formulation of the problem that has been stated, various objectives 
can be taken, including (1) Finding out the products offered in the Fun Food Barbeque Event at Neo+ Awana Hotel (2) To find out what innovations made by the Food and Beverage Department in preparing Fun Food Barbeque events.

\section{LITERATURE REVIEWS}

According to Crowther (1992) in the Oxford Dictionary Advance Learner's Encyclopedic Dictionary, hotel defines as: "Building where meals and rooms are provided for travelers." This definition can be interpreted as a building (physical) that provides room service, food and drinks for guests. According to the American Hotel and Motel Association (AHMA) as quoted by Kasavana (2013): Hotel may be defined as "An establishment whose primary business is providing lodging facilities for the general public and which furnishes one or more of the following services: Food and Beverage service, room attendant service, uniformed service, Laundering of linens and use of furniture and fixtures."

According to Sulastiyono (2011: 5), hotel is a company managed by its owner by providing food, beverage and room facilities for sleeping to people who travel and are able to pay a reasonable amount with services received without special agreements. According to Bagyono (2007: 63) Hotels are a type of accommodation that is managed commercially and professionally, provided for everyone to get lodging, eating and drinking services and other services.

Food and Beverage Department is a division of the hotel, which has the function of selling the food and beverage products. In addition to performing the function of selling food and beverages, it also runs complex activities. The activity is to carry out business development of food and beverage products, plan activities activities that can attract guests to eat and drink at the hotel restaurant, make purchases of food and beverage ingredients, store food and beverage ingredients, carry out processing, serving food and drinks and product calculation (Sulastiyono, 2011).

According to Reguia (2014) product innovation is the development of new products, making changes in the current product design, using new techniques on making products and means in the current production methods, in other words, product innovation is focuses on existing markets for existing products, differentiating through features and functions that current offers of competitors do not have. The product innovation can be look from two sides; internal side where it depends on knowledge, capacities, resources and the technologies used in the company, however; from the external side product innovation focuses on the consumers needs and the owners expectations.

The Food and Beverage Department is part of the hotel that deals with the supply and sale of food and beverages in the hotel. In addition to renting rooms for a hotel food and drinks are the sources of certain income (Damardjati, 2006: 55). The Food and Beverage Department is one of the departments or sections within a hotel with the main role of organizing services and drinks for hotel guests, leaders and employees and is the biggest result for hotels - generally starred hotels are from food and beverage sales in restaurants, room service, banquet. Innovation is a new creation (in the form of manifestations or intangibles) that has a 
significant (significant) economic value, which is generally carried out by the company or sometimes by an individual. Innovation is an idea, action, or something new in a particular social context to answer the problem at hand (Ansyar, Nurtain: 1991)

\section{METHODS}

This research uses qualitative research method. Qualitative research method is a method to obtaining and collecting qualitative data, so the 'qualitative' is not actually the method, but the types of data. Qualitative data are not numeric or statistic units, but the data is presented based on observations of statements regarding the content, nature, characteristics, circumstances, of something or symptoms, and statements about the relationships between something and something else. Something in this case can be physical objects, behavioral patterns, ideas, values, norms, and events that occur in a community's life.

According to Moleong (2010), the process of research and collecting the data in qualitative methods are based on methodologies that investigate social phenomena and problems within the scope of science. The author of this approach makes a complex picture, examines words, detailed reports from the views of the subject and conducts studies on natural situations. Procedure Writing and processing data using qualitative methods produces a descriptive presentation in the form of written or oral words from people and behavior observed at the location of Writing, namely Neo+ Awana Hotel Yogyakarta.
There are two types of data to be searched, namely primary data and secondary data. The primary data is data obtained as long as the author makes direct observations when carrying out fieldwork practices and uses interviews sourced from the Department of Food and Beverage and Sales and Marketing Department at $\mathrm{Neo+}$ Awana Hotel Yogyakarta. The secondary data is data obtained through books, brochures, and articles contained in print and Internet media.

The collecting data techniques carried out at Neo+ Awana Hotel Yogyakarta to obtain the necessary data sources, the techniques used by the authors are observation, interviews, documentation and literature. Observation is the activity of collecting data by observing directly at the Food and Beverage Department of $\mathrm{Neo}+$ Awana Hotel Yogyakarta. The observation was carried out as long as the author underwent training at $\mathrm{Neo}+$ Awana Hotel Yogyakarta, which included preparatory activities for the Fun Food Barbeque Event and set up menu. Interviews are data collection activities by the way the writer interacts with related parties through direct question and answer to get the information needed. Interviews were carried out to parties in the Food and Beverage Department section, both in the Food and Beverage Product and Food and Beverage Service section to complete the author's data.

The next data collection technique is documentation. Documentation is intended to obtain various written documents or data, as well as images that are relevant to the writing done. Meanwhile, the latest data collection uses the literature study method as a reference 
material in finding secondary data related to paper.

\section{RESULTS AND DISCUSSIONS}

Neo+ Awana Hotel Yogyakarta is one of the hotel operator networks, Archipelago International, better known as Aston International. Archipelago International is the largest hotel network in the Southeast Asia region with more than 100+ hotels and 15,000 rooms and more than 95 properties under construction in Indonesia, the Philippines and Malaysia. Aston International is the first company in Indonesia to redefine the concept of a service apartment into a daily hotel and the availability of facilities that allow guests to stay longer. The Aston International Group consists of several sister groups with brand names Grand Aston, Aston, Aston City, Alana, Harper, Quest, Favehotels, Neo and Kamuela, that offers a choice of luxury villas with private pools to economy apartments and hotels, thus tourists can choose as you wish. $\mathrm{Neo}+$ Awana Hotel is a hotel with a threestar plus class. According to the guest speaker, the sales executive of $\mathrm{Neo+}$ Awana Hotel Yogyakarta, which is meant by a three-star plus hotel is a hotel that has three-star facilities but has supporting facilities that are more than three-star. Hotel support facilities are based on hotel classification regulations by management of Archipelago International Indonesia (AII).

One of the supporting facilities in selling Food and Beverage products and services at Neo+ Awana Hotel Yogyakarta is The Noodles Now Restaurant. The Noodles Now Restaurant is located on the $1^{\text {st }}$ floor of Neo+ Awana Hotel Yogyakarta. The Noodles Now Restaurant offers a mixed menu including Indonesia, Western and Chinese. The menu consists of a buffet menu including breakfast, lunch and dinner and the a la carte menu. The restaurant hours start from 06.00 to 23.00 WIB and room service is open for 24 hours in the form of a la carte menu. The restaurant is divided into 2 parts.

1. The Outdoor Restaurant. The outdoor section is located next to the swimming pool and is intended for the smoking area. In the outdoor section, guests can see the view of the swimming pool and vertical garden. The concept of the outdoor section is natural with the existence of a vertical garden, chairs and tables made of wood and rattan, besides that in this section there are several bird cages that are singing. The birds are indeed provided by the hotel to add a natural impression.

2. The Indoor Restaurant. The indoor part is a room that uses air conditioning, in this room the concept used is modern contemplation, namely the use of modern furniture but with contemporary decoration on the walls.

\section{Fun Food Barbeque}

Food Barbeque Fun at Neo+ Awana Hotel is a buffet menu at a price of IDR 80,000 all you can eat (AUCE), so guests cannot buy one of the products in the Fun Food Barbeque Event. The menu consists of appetizer, main course, grilled, soup and dessert. The menu that is presented is western food. As for the Fun Food Barbeque Event menu provided by the Department of Food and Beverage includes: 
1. Grilled Foods

a. Fresh beef: Use part of the tenderloin slice cut in size $6 \times 4$ $\mathrm{cm}$. Then marinate with salt, paper and mustard for 10 minutes. Furthermore, the beef is arranged on a plate and then displayed using ice below it to keep the beef fresh.

b. Fresh chicken: Use the breast meat, and the pieces are the same as beef cuts. Then marinate using rosemary, salt and paper.

c. Fresh seafood: Consists of groupers, green clams, squid and shrimp. The fish is cut from darne, but for green mussels it remains intact.

d. Various kinds of satay: The satay menus consisting of satay sausage, chicken satay, meat satay (Figure 1).

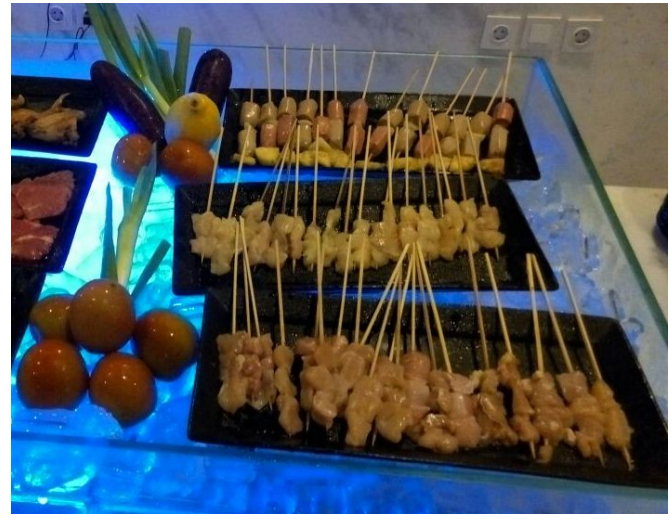

Figure 1. Various Kinds of Satay

Source: Research documentation, 2016

2. Main Course by Buffet

For the main course menu provided by western food include butter rice, sauted vegetables, bake jake potatoes, corn on the cob, lemon fish sauce, chicken picatta, lasagna and pasta.
3. Appetizers

For appetizers provided include vegetable roll, Waldorf salad and fruit salad (Figure 2).

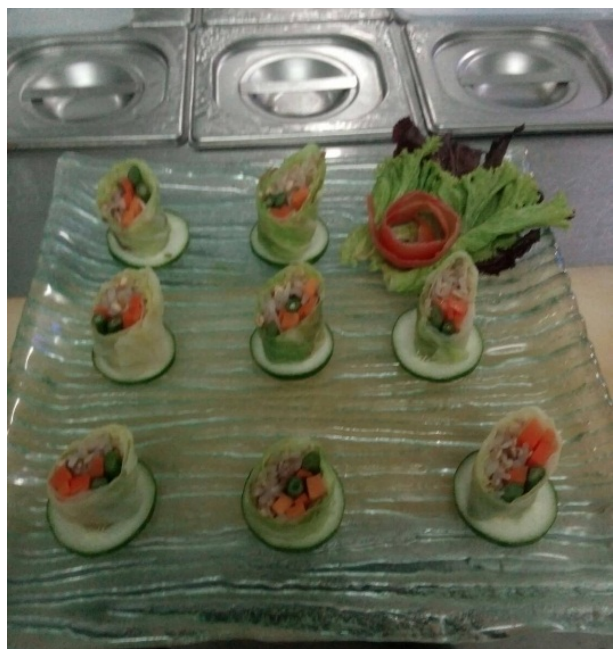

Figure 2. Vegetable Rolls

Source: Research documentation, 2016

4. Soups

The soups menu that provided are potato and leek soup, which is served with bread bowl, French bread, and garlic bread. Guests can choose according to their wishes.

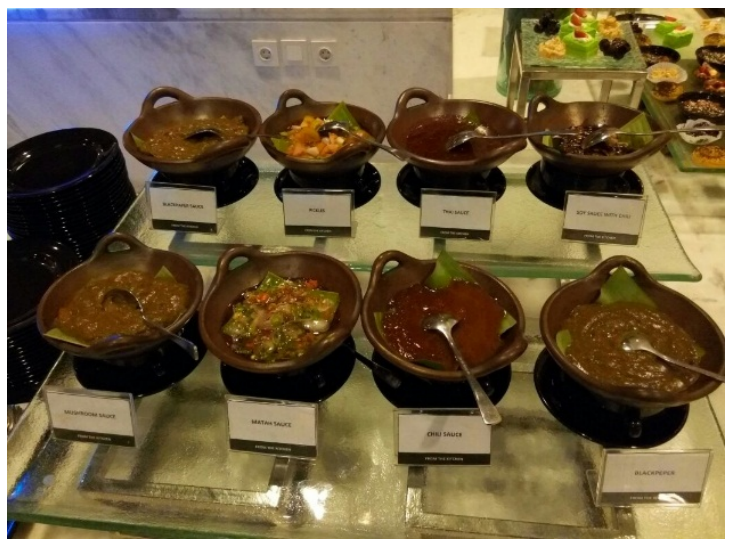

Figure 3. Various Kinds of Sauce

Source: Research documentation, 2016

5. Various kinds of sauce: To complete barbeque dishes, there 
are various kinds of sause including mushroom sauce, blackpaper sauce, chili sauce, Thai sauce, soy sauce with chili, matah sauce and pickles (Figure 3).

6. Desserts

For dessert provided include pudding, caramel banana, tarlet fruit, fruit ice and slice fruit consisting of melon, watermelon, pineapple and papaya (Figure 4).

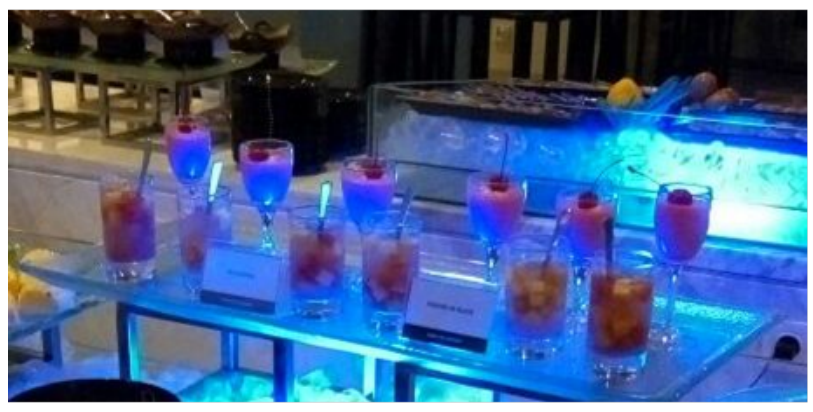

Figure 4. Various Kinds of Dessert

Source: Research documentation, 2016

7. Beverages

For drinks provided, among others, ice water, ice tea and juice, for juice every event is always replaced by taste for variety.

8. Live Cooking

To keep the food served fresh, the choice of the new barbeque menu will be grilled when guests come and choose, then the choice is given to kitchen staff who are at the barbeque stall. Guests can order their own maturity level from the selected product according to taste (Figure 5).

9. Live Music

Event Fun Food Barbeque provides entertainment namely live music, guests can enjoy food accompanied by music from local music grub. Guests can also request songs to be sung by the music group. The music group performance is held in an indoor restaurant or outdoor restaurant, depending on the weather when it is raining, the show will be held in the indoor restaurant but when the weather is good it will be held at the outdoor restaurant, which is next to the swimming pool.

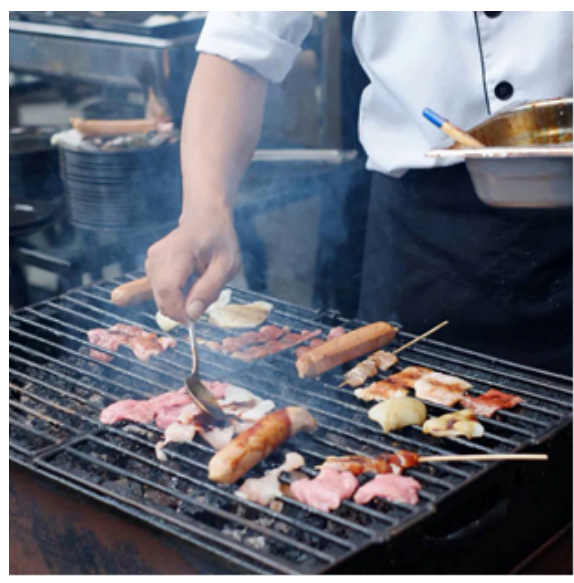

Figure 5. Live Cooking of Barbeque

Source: Research documentation, 2016

\section{The Innovations in Fun Food Barbeque} Event

Innovation in hotel products is required to increase the attractiveness and to gain more revenue. One of them is innovation in Food and Beverage products. The innovative products is important to attract costumers, especially in new opened hotels, which are still innovating to make products from these hotels in demand by consumers. One of the new hotels in the city of Yogyakarta is the Neo+ Awana Hotel which has Fun Food Barbeque products from the Food 
and Beverage department. Fun Food Barbeque products are events at the $\mathrm{NeO}+$ Awana Hotel held every Saturday. The event aims to increase hotel revenue in the field of Food and Beverage.

Andri Juni is an Executive Chef since the hotel was inaugurated in March 2015. The Pioneer of the Event Fun Food Barbeque is the first Chef at the $\mathrm{NeO}+$ Awana Hotel. He made a Fun Food Barbeque with a European theme. At the beginning the event was held, it was still quiet and there were not many reservations, but after a few months the event began to get crowded. Then when the writer did the writing, in the kitchen section the staff was experiencing a vacancy of staff namely Executive Chef, therefore there were many obstacles that occurred when preparing for the Fun Food Barbeque event, including no person in charge to check food before serving, so the task was taken over by chef de partie therefore the food served is not optimal. These constraints cause food presentation to decline. In addition, the lack of innovation has caused the Fun Food Barbeque to become monotonous, it can be look from the food served always with the western food theme, so that guests are reduced and the Fun Food Barbeque Event becomes quiet. The vacancy lasted for 2 months, then in April the position was replenished by the new Executive Chef, Chef Ari Yusuf.

After the new Executive Chef, the Fun Food Barbeque Event changed its theme from Europe to a mix between Indonesia and Europe. These changes are food innovation and presentation. The following is an explanation of food innovation and its presentation:

1. The Changes of Menu

The menu changes are presented by changing the menu which was originally pure western food into fusion food, fusion food is a blend of Indonesian and European food. The menu changes in Fun Food Barbeque include:

a. Grilled Menu

This menu is changed to Indonesian food including Javanese chiken skewer, maranggi satay, goat's satay, chicken and beef saussages, Bali grilled fish, grilled mussels, sweet corn and vegetable skewer.

b. Appetizer Menu

The appetizer menu served is converted into a blend of western salad with Indonesian salad, namely salad bar and condiment, pecel ndeso, hodgepodge and chicken lawar. The combination of Indonesian salads and western salads is because not all guests like one type of salad besides the guests who come to the event are domestic and foreign guests. Therefore, the salad served is a blend of Indonesian and western salads, so guests can choose according to taste.

c. Soup Menu 
Changes to the original soup are potato and leek cream soup to Soto Bogor (Figure 7). This change in the menu of Soto Bogor is served in a cart stall to add a traditional Javanese impression. However, the changes to the soup condiment menu are not eliminated, namely french bread, because if guests do not like rice, it can be replaced with French bread.

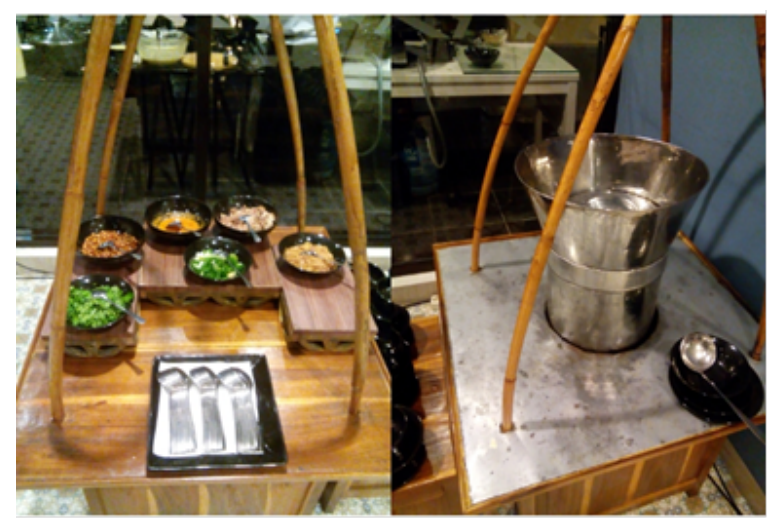

Figure 7. Soto Bogor Stall

Source: Research documentation, 2016

d. Main Course Menu

The Main Course menu at the beginning of the Fun Food Barbeque Event is western food, all then converted into Indonesian food including white rice, brown rice, potato spicy balado, lodeh Wonosari, Javanese fried noodles, betutu chicken, Padang beef rendang and Solo goats tongseng.

e. Dessert Menu
Dessert served at Barbeque Fun Food, which has been converted into a mixture of Indonesian, and western dessert, the menu includes assorted panna cotta, cream brulle, mini tarlet, assorted pudding, and assorted sweet fruits. In addition, the fruit served is not only slice fruit, but now added with assorted whole fruit, including apples, oranges and zalacca.

f. Any Kind of Sauce.

Sauce provided in the Fun Food Barbeque Event was changed to Indonesian sauce, including matah sambal, dabu - dabu spicy sambal, onion chili and lime chili sauce, soy sauce, soy sauce with chili, chili sauce and tomato sauce.

2. Adding the Food Stalls

The previous Fun Food Barbeque event was not having food stalls, then Executive Chef was added to the stall. The stall is egg martabak (Figure 8), full moon cake and Javanese boiled noodles. Each stall is headed by one kitchen staff and served with live cooking, its keeping food always fresh. In addition, live cooking became guest's attractions at the Fun Food Barbeque event. 


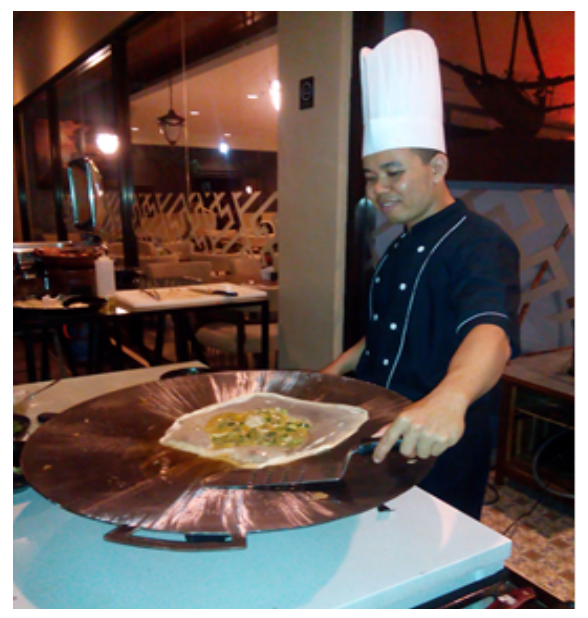

Figure 8. Live Cooking Stall of Eggs Martabak

Source: Research documentation, 2016

3. Food Presentation

Food presentation at the Fun Food Barbeque event that has been changed becomes more maximal. The maximum presentation of food can be seen from the appearance of a neater food and with additional fruit carving so that it adds to the appearance of the food becomes more attractive. The

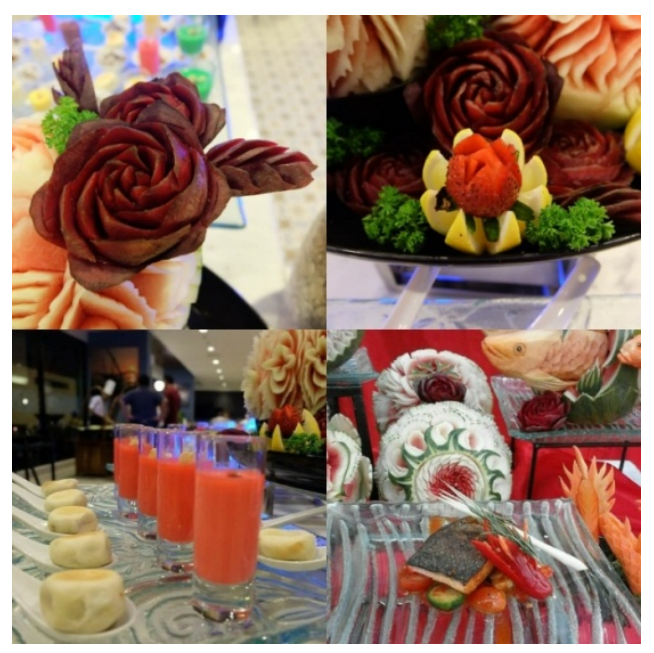

Figure 9. Fruit Carving

Source: Research documentation, 2016
Fruit Carving is always replaced with the theme of flowers, plants, animals and characters, for example, floral, plant and animal motifs (Figure 9).

\section{CONCLUSION}

The implementation of Fun Food Barbeque event can be concluded that the Fun Food Barbeque product after its product innovation has become more attractive and innovative. Barbeque, which originally served western food, was not too popular with guests because barbeque products with many western food menus offered mainly in star hotels. The innovation of transforming barbecue products into fusion food, namely by mixing a menu of Indonesian food with western food, the Fun Food Barbeque event becomes more interesting. The winnings were mainly shown to guests from overseas, the authors saw that foreign guests were more interested in trying these products because they rarely found such products.

In addition to the innovation of food products, the product presentation at the Fun Food Barbeque Event is more maximal, it can be seen from the use of earthenware and stall carts for soup which adds to the impression of traditional food and fruit carving at the event adds more maximal food presentation.

Based on the author's description on the discussion chapter, some suggestions can be conveyed, among others, which are: (1) Improving product presentation at the Fun Food Barbeque Event, namely paying more attention to food garnish, (2) Adding the source of kitchen staff to avoid employee vacancies especially in important positions, and adding employees in accordance with 
their fields so that the services provided are more maximal, (3) Adding the source of kitchen utensils in each section in the Food and Beverage Department to be more efficient in working, (4) Adding the source of supporting infrastructure means air conditioning in the cold kitchen room to keep food awake freshness.

\section{REFERENCES}

Ansyar, Mohd \& H. Nurtain. (1991). Pengembangan dan Inovasi Kurikulum. Jakarta: DEPDIKBUD DIKTI.

Arismagita, Iban. C. (2016). Fun Food Barbeque sebagai Inovasi Produk Food and Beverage Department Hotel Neo+ Awana by Aston Yogyakarta. Tugas Akhir Universitas Gadjah Mada.

Bagyono. (2007). Pariwisata dan Perhotelan. Bandung: Alfabeta.

Crowther, Jonathan. (1992). Oxford Advanced Learner's Encyclopedic Dictionary. Oxford: Oxford University Press.

Damardjati, R.S. (2006). Istilah-istilah Dunia Pariwisata. Jakarta: PT. Pradnya Paramita.

Kasavana, Michael L. (2013). Managing Front Office Operations $9^{\text {th }}$. Lansing, Michigan: AHLEI.
Moleong, Lexy. (2010). Metodologi Penelitian Kualitatif. Bandung: Remaja Rosda Karya.

Reguia, Cerroun. (2014). Product Innovation and The Competitive Advantage. European Scientific Jurnal, Vol 1. 1. 2014 P140-157.

Sulastiyono, Agus. (2011). Manajemen Penyelenggaraan Hotel. Seri Manajemen. Usaha Jasa Sarana Pariwisata dan Akomodasi. Bandung: Alfabeta.

Tribun Jogja. (2015). Hingga Tahun Depan, Tercatat Total 110 Hotel Baru Akan Dibangun di Yogya http://jogja.tribunnews.com/2015/12 /07/hingga-tahun-depan-tercatattotal-110-hotel-baru-akan-dibangundi-yogya.

UNWTO. (2012). Press Release: International tourism to reach one billion in 2012. World Tourism Organisation, Madrid. http://media.unwto.org/en/pressrelease/2012-01-16/internationaltourism-reach-one-billion-2012. 